\title{
E TU AKE! INVESTMENT IN WĀHINE MĀORI AND PASIFIKA WOMEN
}

\author{
Riripeti Reedy \\ Ministry For Women \\ Disclaimer: The views, opinions and conclusions expressed in this report are intended to inform and stimulate wider debate. They do not \\ represent government policy.
}

\begin{abstract}
Increasing the economic contribution of women who are at risk of having low lifetime incomes is a priority of the Ministry of Women's Affairs. Using the Māori and Pacific Trades Training initiative as a policy entry-point, this paper re-examines data related to this target group and explores the implications of this 'new' data to contribute to improving the economic independence of Mãori and Pasifika women with low or no qualifications. Drawing on the findings of the E Tu Ake! Stand Tall and Proud report released by the Ministry for Women, the paper extends those findings to better direct us as policy makers and influencers within the broader policy-workforce interface and in our discussions with employers to more relevantly support these women.
\end{abstract}

\section{Public Policy settings}

The Ministry for Women welcomes the opportunity to be a part of innovative and solutionsfocused policy work. Being able to point to the real and different experiences of women in work, in the economy and in the private spaces of their homes and incorporating their everyday encounters in the myriad of environments they occupy is part of the development and embedding of gender as a framework of analysis in public policy making. In its role as the principal advisor on achieving better outcomes for New Zealand women ensuring that the diverse voices of women are brought to the attention of government is central to all of the Ministry's policy development.

Political economic theory that vests all decision-making in the rational individual to maximise their best life decisions has dominated public policy settings for the last twenty years. For at least the past five, a whole-of-government approach to expand the understanding of policy issues in a wider system context has been cemented in the Better Public Services priority of government. In spite of these efforts the persistence of pockets of poverty for our most vulnerable families that are most often women led, and the social inequality that exists in our society urges public policy makers to innovate beyond the frameworks used to date.

A finer grained look at the census numbers pertaining to a specific region provides accessible evidence-based information that the paper suggests offers up new analytical approaches to action and change for wāhine Māori and Pasifika women. These are important influencing policy contributions of the Ministry.

\section{Methodology}

Hence, this paper does not report new data. It utilises only what is currently and easily available from the Statistics New Zealand 2013 census, area unit data that relates to the four Auckland local board areas: Mangere-Otahuhu; Otara-Paptoetoe; Manurewa and Papakura. These board 
areas comprise the south Auckland-Southern Initiative area. Against a backdrop of low and extremely low income, the gender and ethnic data presented uncovers in a region already identified as 'diverse', extremes of social, economic and cultural experiences.

\section{Background}

The E Tu Ake! Stand Tall and Proud report prepared by the Ministry for Women and published in March 2014 identified that programmes that respond to the needs of women not in employment education or training (NEET), Māori and Pasifika NEET women and women with fewer skills and low incomes are:

- partnered between multiple organisations

- link women with employers who have real jobs

- are aligned to the skills needs of those real jobs, and

- provide support after employment, when the effects of getting to work, being at work and home issues become good habits of these women and their households.

In taking the Ministry's thinking and further work with these women forward, participating in the government officials group for Māori and Pacific Trades Training is an obvious area of overlap and contribution. As well, the issues of gender, culture and childcare resonate across the workspace for all women but have particular implications for wāhine Māori and Pasifika women for whom culture and gender remain contested spaces of identity.

\section{The Māori and Pacific Trades Training (MPTT) initiative}

The Ministry of Business, Innovation and Employment (MBIE) states that:

The aim of the Māori and Pacific Trades Training initiative is to enable more Māori and Pasifika learners, aged 18-34, to obtain meaningful trades apprenticeships and qualifications. The end goal is that all participants gain skilled and sustainable employment. With demand for skilled tradespeople expected to be high over the next several years, the government is working to align pre-trades training with employers and iwi, and increase employment opportunities for Māori and Pasifika learners to enter into workplace trades training. Key to New Zealand's economic success is raising the skill levels of Māori and Pasifika peoples who will make up increasingly larger proportions of our national workforce in the future. (www.mbie.govt.nz)

A strategic difference to engage and support the MPTT programme has been the development of a consortia approach. This has been implemented by MBIE, the Tertiary Education Commission (TEC) and the Ministry of Education (Education), lead agencies of the MPTT initiative. Consortia are the contracting partners with MBIE and TEC to the deliver the programme. Consortia have been required to include (i) Institutes of Technology and Polytechnics (ITPs) or training providers, (ii) local Māori and/or Pasifika communities, or iwi, and (iii) employers. These consortia partners are expected to demonstrate robust decision-making relationships that will better support Māori and Pasifika learners into work, via a New Zealand apprenticeship.

This is a new approach. Formally including more than just the ITP-training provider to make financial and learning decisions for Māori and Pasifika learners is a first.

It is also a new contractual approach. Appendix 1 details the 12 contracted consortia and the lead consortia partner that will receive specific MPTT related funding. While five of these are led by ITPs, significantly, five have been signed by iwi and two by community, represented through 
the Hawkes Bay Youth Futures Trust and the Auckland Council. As contracted partners to deliver the learner and employment outcomes attached to the initiative, the level of financial disclosure for iwi and community are new. Consequent budget negotiations and allocations along with direct employer involvement add richness and opportunity to these new contractual relationships and their processes of delivery.

The Ministry for Women considers consortia might be one of the step-changers to achieve more effective Māori and Pasifika participation in tertiary education. Enlarging the consortia perspective to automatically include wāhine Māori and Pasifika women in all of their expectations is a specific outcome the Ministry for Women seeks.

\section{The Southern Initiative (TSI)}

Our work as officials identified that considering the issues of gender, culture and childcare in a way that is focussed and informing, was likely to be far more impactful in 'the world capital of Pasifika Peoples' and where the highest concentration of Māori are to be found - Auckland, or more specifically, south Auckland. Examining the available data relating to this area led immediately to the Auckland Council's work on the Southern Inititative, as noted earlier, also the consortia name of the Māori and Pacific Trades Training consortia the Council leads.

\section{Map 1. The Southern Initiative Profile}

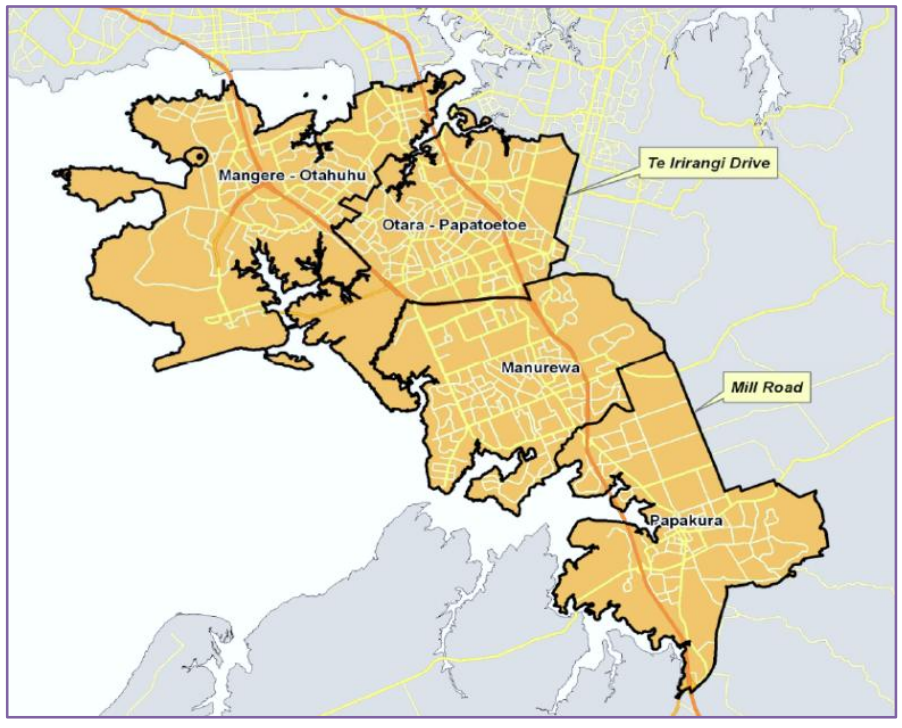

The Southern Initative encompasses four

Auckland local board areas: 1. Mangere-Otahuhu, 2. Otara-Papatoetoe, 3. Manurewa, 4. Papakura.

The Southern Initiative, as described by the Auckland Council, is one of two big place-based initiatives in the Auckland Plan, with significant economic opportunity yet high social need. Its purpose is to "plan and deliver a long-term programme of co-ordinated investment and actions to bring about transformational, social, economic and physical change" (Auckland Council 2014:4).

Tied to this, the Council has identified the Southern Initiative as an opportunity to improve the quality of life and wellbeing of its residents and reduce growing economic and social disparities. 
Table 1: The Southern Initiative - overview

\begin{tabular}{|c|c|c|}
\hline $\begin{array}{l}\text { 1. The people are more } \\
\text { diverse: }\end{array}$ & $\begin{array}{l}\text { Total Population } \\
\text { Ethnicity } \\
\begin{array}{l}\text { Age - median } \\
\text { - children (0-14 yrs) }\end{array}\end{array}$ & $\begin{array}{l}\begin{array}{l}274,494=6.5 \% \text { of } \mathrm{NZ} \\
\text { popln }\end{array} \\
\text { 40\% Pasifika } \\
\text { 32\% European } \\
20 \% \text { Māori } \\
21 \% \text { Asian } \\
29.8 \text { yrs } \\
26.6 \% \text { of total TSI }\end{array}$ \\
\hline 2. They sound more diverse: & Speak English and... & $\begin{array}{lr}\text { Samoan } & 14.1 \% \\
\text { Hindi } & 7.8 \% \\
\text { Māori } & \\
\text { Tongan } & 5.9 \% \\
\end{array}$ \\
\hline $\begin{array}{l}\text { 3. TSI supports different } \\
\text { lifestyles: }\end{array}$ & $\begin{array}{l}\text { Households } \\
\text { Families }\end{array}$ & $\begin{array}{l}11 \% \text { are } 2 \text {-family h/h } \\
44 \% \text { of Akl's } 3+\text { family } \\
\text { h/h } \\
28 \% \text { are One Parent w } \\
\text { childn }\end{array}$ \\
\hline 4. It is poor: & Income median & $\begin{array}{r}\$ 23,000 \text { vs Akl } \$ 29,600 \\
\text { vs NZ } \$ 28,500\end{array}$ \\
\hline
\end{tabular}

An initial review of the 2013 census data confirmed the Southern Initiative comprises a significant proportion of the country's population within its boundary. It is a young, brown (Pasifika brown, Māori brown and Indian-Asian brown), and poor population. A median personal income of $\$ 23,000$ makes the TSI a distinctively poorer part of Auckland which has a median personal income of $\$ 29,600$ higher even than the national median personal income of $\$ 28,500$. Almost 30 percent of the TSI residents speak a language other than English. The link between ethnic-cultural practices and the spoken language of the home is another important characteristic of diversity of the Southern Initiative population. Added into this mix, almost 30 percent of households are one parent households with children. Most of these households are women-led households.

\section{The Census Data - a 'finer grained look'}

Aside from the data telling us 'what we already knew' that TSI is young, brown and poor and the further south one travels, the 'older, whiter and wealthier' it becomes, linking the data to ways in which we might achieve outcomes that will engage more Māori and Pasifika women to succeed as participants in the MPTT initiative begs, we think, a new and different way of presenting and understanding the data. As the basis of this inquiry, a finer grained look, using the 2013 Census Area Unit data for each of the local board areas threw up some disturbing extremes amongst the TSI resident population. 
Table 2: Mangere-Otahuhu

\begin{tabular}{|l|}
\hline Mangere-0tahuhu: 70,959 : 25.8\%of TSI \\
\hline E: $19.5 ;$ M $15.9 ;$ P: 60.1; A: 17.2. \\
\%b.0'seas: $43.2 \%$ Sa \\
\hline Lang Sa 19.1 \\
\hline 1Lang: 51.0 \\
\hline Age: 28.3 \\
\hline u.15yrs 28.1 \\
\hline 1Pw childn 30.1 \\
\hline H/H size 4 \\
\hline Inc: $\$ 19,700$ \\
\hline Shaded Area Units: 44,366 pple \\
\hline \$15,600; Viscount, Fairburn \\
\hline Mascot; Harania N\&W\&E \\
\hline Favona W\&N; Arahanga \\
\hline Otahuhu W\&N, Mangere C, 18,700 \\
\hline Aorere 19,500 \\
\hline
\end{tabular}

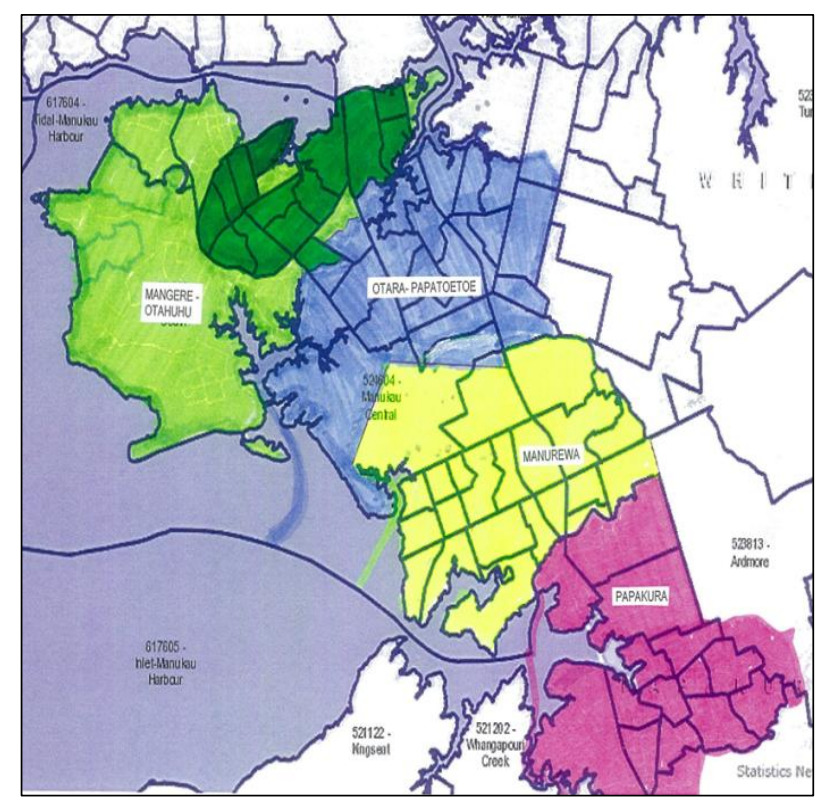

The 13 shaded area units in the Mangere-Otahuhu map attached to Table 2 are those with median personal incomes lower than the board's median personal income of $\$ 19,700$. They range from $\$ 15,600$ in Viscount to $\$ 19,500$ in Aorere. Together these shaded areas account for a neighbourhood population of 44,366 . As a comparator, Gisborne city has 46,600 residents. This local board area also recorded 60 percent of its residents as Pasifika with almost half of them speaking English and another language. In an hypothetical village of 11 people only two are Pakeha. While one-parent households with children account for almost $18 \%$ of families in the New Zealand population, locally they account for just over 30 percent of these families.

Table 3: Otara-Papatoetoe

\begin{tabular}{|l|}
\hline Otara-Papatoetoe: $75,663: 27.5 \%$ of TSI \\
\hline E: $20.7 ;$ M 15.6; P: 45.7; A:30.9. \\
\%bO'seas: $46.6 \% \mathrm{Fj}$ \\
\hline Lang Sa 16.7 \\
\hline 1Lang: 52.1 \\
\hline Age: 29.3 \\
\hline u.15yrs 25.9 \\
\hline 1Pw childn 27.8 \\
\hline H/H size 4 \\
\hline Inc: $\$ 21,100$ \\
\hline Shaded Area Units: 22,000 pple \\
\hline 13,300 Otara W \& N \\
\hline Otara S 15,600 \\
\hline Fergusson, 14,500 \\
\hline Rongomai, 16,100 \\
\hline
\end{tabular}

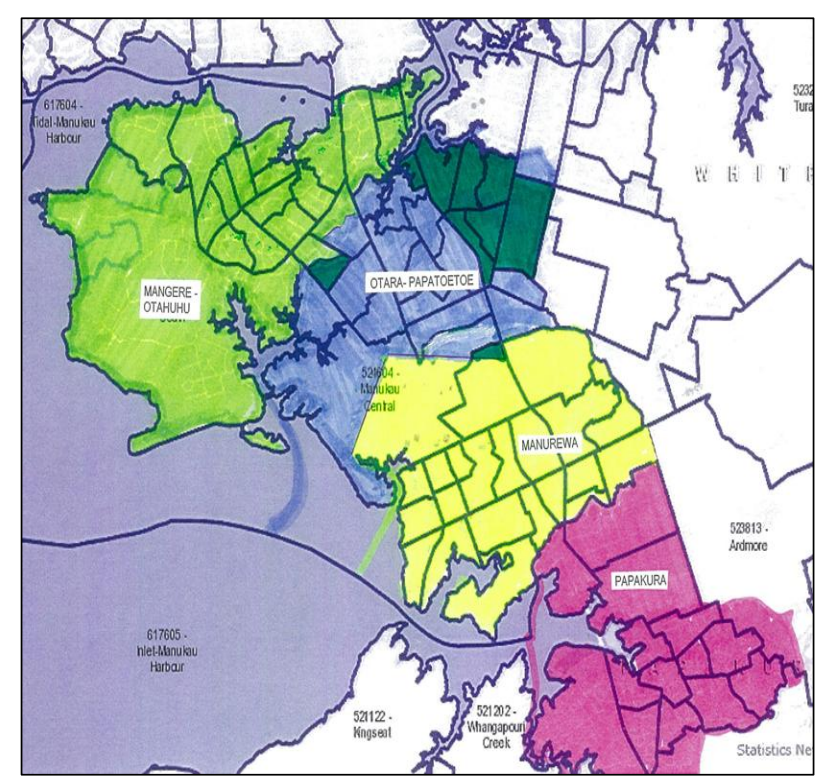

Otara-Papatoetoe remains a brown population, and although a strong Pacific presence continues, there is a significant group of Asians, almost 31 percent. Calling them Asians however is misleading. These Asians are in fact Indian and account for almost half of this local board population being born in Fiji. It then makes sense that in the Southern Initiative, after English and Samoan, Hindi has become the next most spoken language. 
The shaded area units in the north encompass Otara where the lowest personal medium incomes in the TSI are recorded and start at $\$ 13,300$. Approximately 22,000 people live in these poor neighbouring streets.

Table 4: Manurewa

\begin{tabular}{|l|}
\hline Manurewa: $82,242: 29.9 \%$ of TSI \\
\hline E: 36.8; M:25.3; P: 33.0; A: 20.3. \\
\%bOseas 35.4 Sa \\
\hline Lang S.12.3 \\
\hline 1L 62.3 \\
\hline Age 29.8 \\
\hline u.15yrs 27.0 \\
\hline 1Pw childn 27.9 \\
\hline HH size 3.6 \\
\hline Inc $\$ 24,700$ \\
\hline Shaded area units: 44,391 pple \\
\hline 16,600 Wiri, 17,800 Clendon N\&S \\
\hline 18,600 Homai E, Rowandale \\
\hline 20,100 Beaumont, Manurewa E\&C \\
\hline Leabank, Hyperion, Weymouth E \\
\hline Burbank, Homai W, 23,100 \\
\hline
\end{tabular}

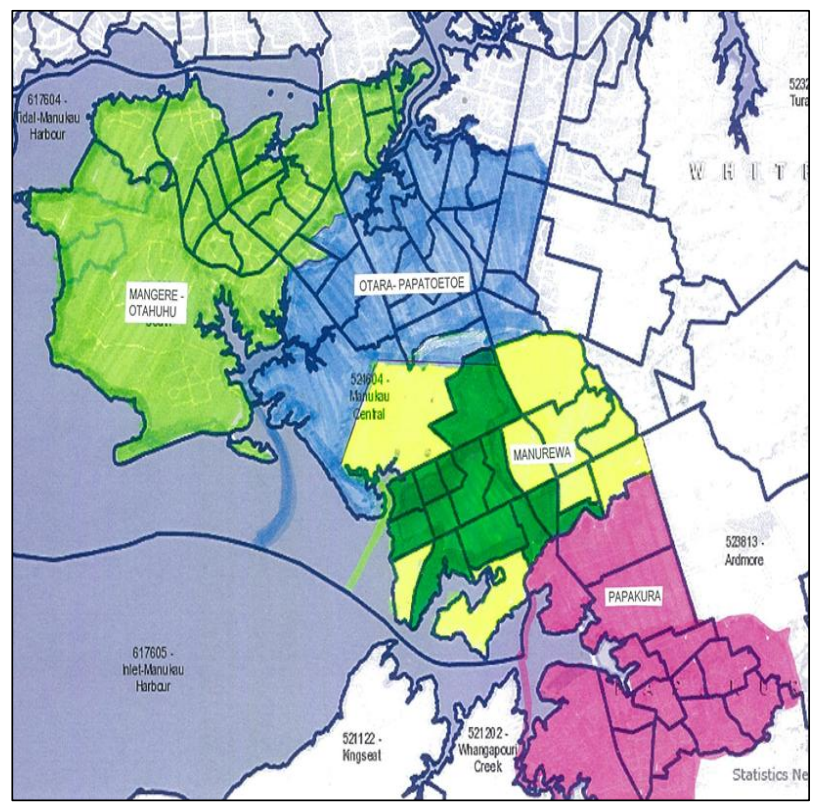

Manurewa is the most populous of the four local boards. Although it still comprises a distinctly polynesian population there are about 30,500 Pakeha living locally. The median personal income has increased to $\$ 24,700$ and below that, the range begins at $\$ 16,600$ in Wiri. Although the Table descriptors record subtle changes of increased incomes and lower household sizes and a lower proportion of one-parent, mainly women-led families, on the whole, Manurewa remains significantly and negatively different from the national average.

Table 5: Papakura

\begin{tabular}{|l|}
\hline Papakura: $45,636: 16.6 \%$ of TSI \\
\hline $\begin{array}{l}\text { E: 61.1; M:28.1; P: } 14.5 ; \mathrm{A}: 12.8 . \\
\text { \%bOseas 23.5 Eng }\end{array}$ \\
\hline Lang M. 6.0 \\
\hline 1L 77.2 \\
\hline Age 33.1 \\
\hline u.15yrs 24.4 \\
\hline 1Pw childn 27.5 \\
\hline HH size 3 \\
\hline Inc $\$ 28,000$ \\
\hline Shaded area units: 23,538 pple \\
\hline 19,600 Papakura N/E\&C\&S \\
\hline 25,400, Takanini N, \\
\hline RedHill 27,100 Massey Pk 26,600 \\
\hline Rosehill 25,400 \\
\hline
\end{tabular}

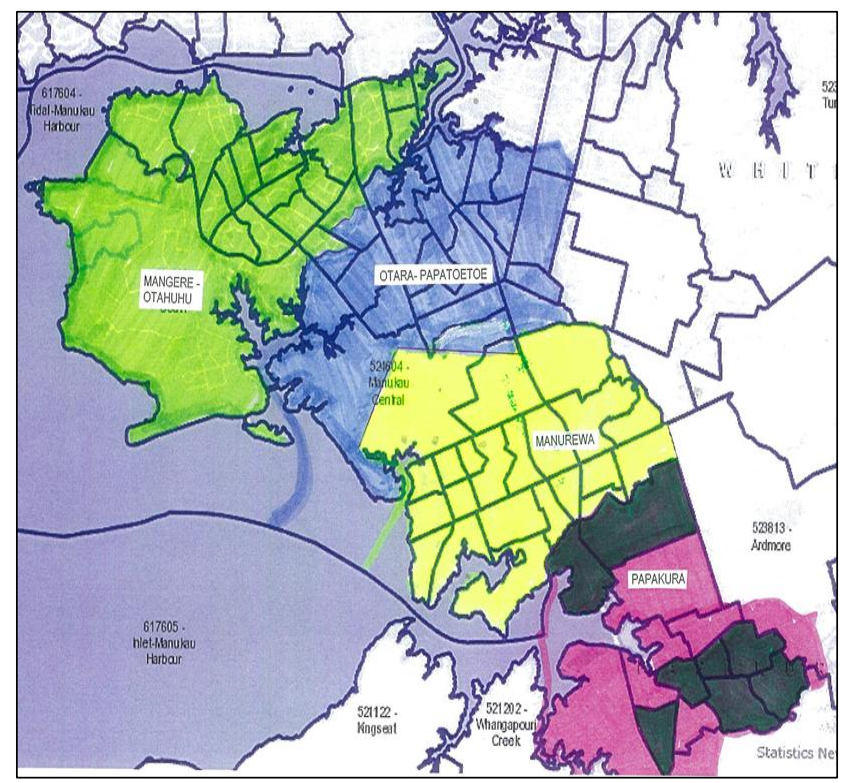

Papakura at the southern end of the TSI, on most descriptors, most resembles 'average New Zealand'. The percentage of residents born overseas is the lowest in the TSI and slightly lower than the rest of the country. Interestingly, these residents were born in England. 
A diverse ethnic population is still apparent with twice as many Samoans (14.5\%) as the national average (7.4\%) and almost twice as many Māori $(28.1 \%)$ as the national average (14.9\%) living in Papakura. And, in our village of 11 people there are now six Pakeha. The personal median income of $\$ 28,000$ is only $\$ 500$ less than the national figure. The median age of 33 years is younger than the national median age of 38 years but still older than the TSI median age of just under 30 years. Compared with the other three local boards that make up the Southern Initiative, Papkura is 'older, whiter and wealthier'.

The data reveals some extremes

A finer grained review of the data reveals some concerning extremes of income and inequality. It also uncovers cultural divides that are emphasised and compounded by ethnicity, language, household size and family types. It draws stark attention to the naming or perhaps more accurately, the mis-naming of a growing ethnic and cultural group. These are all matters of significance when 'counting' people. They become critical when one begins to describe them.

Policy making

An essential component of policy making is to develop understanding of the issue at hand and propose options. These descriptions often rely on arms-length studies and census or other nationally collected data sets. As we have seen here, descriptions evinced from an aggregated data set and those from the same data set when the data is more finely disaggregated has thrown up some distinctive and different highlights on the same situation. We can suppose that policy options based on less detailed understanding, particularly of Māori and Pasifika women's lives, increases the risk of missing its intended audience and anticipated outcomes.

In the Southern Initiative language and ethnic-cultural practices are markedly different from 'average' New Zealand. Added to this, the nuances of English as the medium of spoken language across cultures is contested and uncertain. These are aspects of policy development and the implementation of policy options, that continue to make it challenging. And, just as gender is always a socio-political construction, for wāhine Māori and the many ethnic Pasifika women of New Zealand, 'colonialism and the politics of difference' remain as additional complexities in the negotiations of the gender identities they will assume for themselves, at any given point in time, as women of this land.

As a matter of public policy, increasing the level of participation of wāhine Māori and Pasifika women on the Māori and Pacific Trades Training programmes is rightfully a priority of the Ministry for Women. Contributing to discussions and frameworks that privilege the diverse and different lives of women and propose options that more accurately describe and potentially effect their desired changes is one of the Ministry's key objectives.

\section{Concluding remarks}

Two papers presented at the recent LEW Conference, Links between parenthood and NEET status prepared by Molloy, S and Potter, P (Ministry for Women) and Mothers in the New Zealand workforce prepared by Flynn, S and Harris, M (Statistics New Zealand) are examples of finergrained statistical analyses on issues that crossover into this area of investing in wāhine Māori and Pasifika women. Further research that centralises Māori and Pasifika women as the primary lense of analysis is required. 
From the work undertaken here and the presentations of the two aforementioned papers, deeper and more nuanced descriptions of these brown women are available.

In a similar vein, policy frameworks that mainstream difference and diversity are also required. Room (2011) notes the inadequacy of institutional analyses to understand the complex interactions between individual actors and the institutional environment that constrains them. Drawing on complexity science and institutionalism he suggests that a complex adaptive system, one in which the human actors are part of a series of nested systems that make up the whole, is a basis from which policy development and knowledge should be structured. As a foundation from which difference and diversity public policy making can be formulated, further inquiry, assisted by Room's notions of a complex adaptive system would be valuable.

\section{Notes}

The 12 contracted consortia (as at November 2014) with the lead consortia partner. Contracts led by ITPs; 1 . Manukau - Unitec - Te Wananga o Aotearoa; 2. Western Institute of Technology WINTec; 3. Waiariki; 4. WELTec - Whitireia; 5. CPIT. Constracts led by iwi; 1 . Te Runanga o Ngai Tahu, 2. Te Runanganui o Ngati Porou, 3. Te Runanga o Turanganui a Kiwa, 4. Te Matarau Education Trust, a northern iwi group. Community led; 1 . Southern Initiative - Auckland Council, 2. Te Ara o Takitimu - Hawkes Bay Youth Futures Trust.

\section{References}

Auckland Council. (2014) The southern initiative profile. (www.aucklandcouncil.govt.nz/EN/planspoliciesprojects/reports/Documents/southerninitiativea areaprofile2013census.pdf )

Ministry for Women(2014) E tu ake! Stand tall and proud. (www.mwa.govt.nz)

Room, G. (2011). Complexity, institutions and public policy. Cheltenham, UK: Edward Elgar.

Statistics New Zealand. (2014). 2013 Census Data

Young, I.M.(2008). A politics of difference. In Bromell, D. (2008). Ethnicity, Identity and Public Policy: Critical Perspectives on Multiculturalism. Wellington, NZ. Institute of Policy Studies, VUW. 